\title{
Immunomodulatory effects of anti-estrogenic drugs
}

AMITABHA RAY*

MONICA FICEK

Saint James School of Medicine

Anguilla, British West Indies

Accepted April 2, 2012
There are substantial experimental, epidemiological and clinical evidences that show that breast cancer pathology is influenced by endogenous estrogens. This knowledge is the foundation upon which endocrine deprivation therapy has been developed as a major modality for the management of breast cancer. Tamoxifen, which functions as a competitive partial agonist-inhibitor of estrogen at its receptor, has been widely used for more than three decades for adjuvant endocrine treatment in breast cancer. Currently, other effective drugs for endocrine therapy include raloxifene, different aromatase inhibitors (particularly third-generation agents) and luteinizing hormone-releasing hormone agonists. In recent years, a growing body of evidence suggests that these drugs can also act as immune modulators by altering the function of various leukocytes and the release of different cytokines. Moreover, there is evidence that anti-estrogens may prove to be beneficial in the treatment or prevention of some autoimmune diseases due to their effects on immune function. However, their immunopharmacological aspects in the present state of knowledge are not precisely comprehensible. Only a clear pathophysiological understanding could lead to an efficient strategy for breast cancer prevention and decrease in the mortality due to this disease.

Keywords: breast cancer, SERMs, tamoxifen, aromatase inhibitors, immunopharmacology

The pathophysiological mechanisms that regulate immune reactions in response to pharmacological manipulation are the subject of immunopharmacology. Therefore, insights into immunopharmacological patho-mechanisms are relevant to both non-immunological and immunological phenomena. Pathophysiologically, estrogens are steroid hormones that affect the growth, differentiation and function of female reproductive organs including the breast. In addition, several epidemiological, clinical and experimental studies have suggested that estrogens are strongly involved in breast cancer pathology $(1,2)$.

\footnotetext{
* Correspondence; e-mail: amitraym@rediffmail.com
} 
Under the influence of luteinizing hormone-releasing hormone (LH-RH) [or gonadotropin-releasing hormone $(\mathrm{GnRH})]$, gonadotropins, viz. luteinizing hormone (LH) and follicle-stimulating hormone (FSH), are released from the anterior pituitary and regulate ovarian secretion of estrogen and progesterone. In postmenopausal women, estrogen biosynthesis occurs principally in peripheral tissue through the conversion of androstenedione (androgen), of both adrenal and ovarian origin, to estrogen. The aromatase enzyme complex is mainly responsible for this conversion and adipose tissue is the main site of peripheral estrogen biosynthesis (Fig. 1). Local production in the target tissue itself, particularly in the breast, can occur as well (3). The increased rate of conversion of androgens into estrogens in peripheral adipose tissue (aromatization) may be responsible for a higher risk of breast cancer in postmenopausal women (4). However, it is possible that all estrogenic effects in breast cancer are mediated through estrogen binding to estrogen receptors (ER), which function as transcriptional factors that regulate the expression of estrogen-responsive genes (5).

Estrogen has been a major target in the treatment of breast cancer since the end of the $19^{\text {th }}$ century (6). This concept was the foundation upon which endocrine deprivation therapy has been developed as a major modality for the treatment of breast cancer (7). Consequently, there have been investigations of the effect of tamoxifen, the prototype of selective estrogen receptor modulators (SERMs), in patients with metastatic breast cancer. Preliminary clinical studies showed anti-tumor activity, leading to its development as an effective drug in the treatment of breast cancer. Subsequently, other anti-estrogenic drugs have been developed such as other SERMs as well as LH-RH agonists (GnRH agonists), aromatase inhibitors and selective estrogen receptor down-regulators/degraders (SERDs) (Table I).

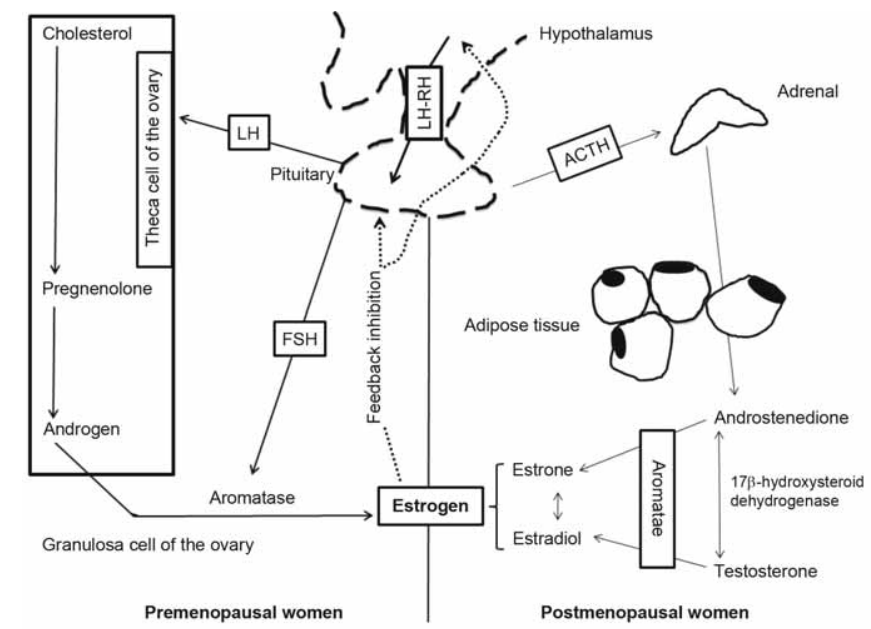

$\mathrm{LH}-\mathrm{RH}$ - luteinizing hormone-releasing hormone, $\mathrm{FSH}$ - follicle stimulating hormone, $\mathrm{LH}$ - luteinizing hormone ACTH - adrenocorticotropic hormone

Fig. 1. An overview of estrogen biosynthesis in the body. 
In premenopausal patients, a strategy proven to be successful is the use of sustained release preparations of LH-RH to cause desensitization of the pituitary gland. As a result, the reduction in gonadotropins causes chemical oophorectomy. Under normal conditions, LH-RH is released from the hypothalamus in a pulsatile manner, resulting in the release of LH and FSH from the anterior pituitary. Continuous administration of an LH-RH agonist (GnRH agonist) over-stimulates the LH-RH receptors in the pituitary, causing an initial rise in LH and FSH. However, after a few weeks, the LH-RH receptors become desensitized, leading to decreased release of FSH and LH. The ovaries then respond by decreasing the synthesis of estrogen (8). In contrast, aromatase inhibitors act on aromatase, which is a useful target because it mediates the last step in the series of steps involved in steroid biosynthesis and is rate-limiting for estrogen synthesis. Steroidal substrate analogues such as formestane and exemestane inactivate aromatase by binding irreversibly to it. Non-steroidal inhibitors such as letrozole and anastrozole are highly potent and reversible inhibitors, with good specificity for aromatase (Table I). Anastrozole, letrozole and exemestane (third-generation aromatase inhibitors) have shown a significant advantage over the traditional aromatase inhibitor aminoglutethimidein in reducing circulating estrogen levels in postmenopausal women (9).

Tamoxifen has been the standard adjuvant endocrine therapy for both pre- and postmenopausal women with ER-positive early breast cancer. However, in postmenopausal women, aromatase inhibitors are more effective than tamoxifen therapy and thus they are presently used as the first line of treatment and tamoxifen as the second line $(10,11)$. In addition to SERMs, a new class of drugs called SERDs have emerged, which interact with and facilitate ER turnover in cells. One drug of this class, fulvestrant, has been approved as a third line treatment for ER-positive metastatic breast cancer (12). Nevertheless, the currently used therapeutic agents are tamoxifen (or raloxifene), aroma-

Table I. Classification of anti-estrogenic drugs.

\begin{tabular}{lll}
\hline Group & Subdivision/characteristic & Drug \\
\hline $\begin{array}{l}\text { Selective estrogen receptor } \\
\text { modulators (SERMs) }\end{array}$ & $\begin{array}{l}\text { Triphenylethylene-based } \\
\text { anti-estrogens } \\
\text { Cyclic/fixed ring anti-estrogens }\end{array}$ & $\begin{array}{l}\text { Tamoxifen, toremifene, } \\
\text { idoxifene, droloxifene } \\
\text { Raloxifene, arzoxifene, } \\
\text { acolbifene, lasofoxifene }\end{array}$ \\
$\begin{array}{l}\text { Selective estrogen receptor } \\
\text { down-regulators (SERDs) }\end{array}$ & Pure estrogen antagonist & Fulvestrant \\
$\begin{array}{l}\text { Aromatase inhibitors } \\
\text { First generation }\end{array}$ & Second generation & $\begin{array}{l}\text { Aminoglutethimide, } \\
\text { testolactone }\end{array}$ \\
$\begin{array}{l}\text { Luteinizing hormone-re- } \\
\text { leasing hormone agonists } \\
\begin{array}{l}\text { (LH-RH agonists) /gonado- } \\
\text { tropin-releasing hormone } \\
\text { agonists (GnRH agonists) }\end{array}\end{array}$ & $\begin{array}{l}\text { Analogue with two substitutions } \\
\text { (at positions 6 and 10) }\end{array}$ & $\begin{array}{l}\text { Formestane, fadrozole } \\
\text { Analogue with single substitution }\end{array}$ \\
\hline
\end{tabular}


tase inhibitors, and LH-RH agonists. Aromatase inhibitors significantly lower the serum estradiol concentration in postmenopausal patients, having no detectable effects on adrenocortical steroid formation. In contrast, LH-RH agonists suppress ovarian function, inducing a menopause-like condition in premenopausal women (13).

\section{TAMOXIFEN: RELEVANT PHARMACOLOGY}

Tamoxifen and raloxifene are so far the only two drugs approved for the chemoprevention of breast cancer (14). Tamoxifen is a derivative of triphenylethylene and is a non-steroidal anti-estrogen. It functions as a competitive partial agonist-inhibitor of estrogen and binds to the ER of estrogen-sensitive normal tissue and estrogen-dependent tumors. Although tamoxifen acts mainly via ER, it also displays anti-tumor activity in ER-negative breast cancer, suggesting other targets. In fact, tamoxifen has effects on several transduction pathways and diverse ion channels (15). Tamoxifen usually has a good tolerability profile and unlike many other endocrine agents, it is efficacious in both preand postmenopausal women. The risk-benefit ratio in regard to the different physiological systems may vary between pre- and postmenopausal women. However, it is the combination of efficacy and tolerability that allows tamoxifen to maintain its position as the hormonal treatment of choice for a considerable number of patients with ER-positive breast cancer. Tamoxifen is extensively metabolized: hydroxylated metabolites 4-hydroxytamoxifen and endoxifen ( $\mathrm{N}$-desmethyl-4-hydroxytamoxifen) have a higher affinity for the ER and are much more potent than the parent drug $(16,17)$. Unfortunately, despite the clear advantage of tamoxifen treatment, not all ER-positive patients respond to it and the initially efficient therapy eventually fails. Tumors may become resistant through different resistance mechanisms, which include alterations in ER structure and function, alterations in post-receptor interactions, changes in paracrine interactions, alterations in drug pharmacokinetics and changes in immunity (18-20).

\section{IMMUNE MODULATIONS BY SERMs}

\section{Tamoxifen}

Effects in breast cancer patients. - It is now clear that tamoxifen treatment modulates immune responses and it has been shown that tamoxifen effects have a close relationship with the host natural killer (NK) cell function. In an earlier study, lymphocytes from tamoxifen-treated patients with breast cancer exhibited a significantly lower activity of NK cells against human myeloid leukemia K562 cells that are killed easily by NK cells in normal situations. In contrast, the proliferative response of lymphocytes to concanavalin A was significantly higher (21). Furthermore, Robinson et al. observed significantly reduced NK cell activity in patients with bilateral primary breast cancer treated with tamoxifen compared to the pretreatment stage (22). They also noticed that those patients showed a decrease in CD4+ T cells and proliferative responses, in an autologous mixed lymphocyte reaction, compared to normal controls. However, among postmenopausal 
breast cancer patients under tamoxifen therapy, Mallmann and Krebs observed an increase in NK cells and a higher number of cases with a positive value in the leukocyte migration inhibition test in comparison with the control group (23). In combination treatment, tamoxifen was reported to be helpful in preventing a decrease of lymphocytes and lymphocyte subset counts during radiotherapy and cytotoxic chemotherapy $(24,25)$. Lukac et al. documented an elevated number of leukocytes including CD4+ and CD8+ lymphocytes in breast cancer patients treated with tamoxifen during the post-radiotherapy period compared to control post-radiotherapy patients. However, granulocyte ingestion was decreased in the tamoxifen group, possibly indicating an inhibitory effect of the drug on phagocytic functions (24).

Effects in human and mouse cell lines. - In a study conducted by Baral et al. using human ovarian and lung carcinoma cases, when cytotoxic T lymphocytes (CTL) were given in conjunction with anti-estrogens, the lysis of autologous cancer cells was significantly increased with both tamoxifen and toremifene (26). This phenomenon was further amplified by additional treatment with interferon-alpha (IFN $\alpha$ ). It was shown through a series of experiments that tamoxifen potentially influenced the lymphocyte population and enhanced the immune cell-mediated target-cell destruction by using ascites fluid of ovarian carcinoma patients, human lung cancer tissue and the P815 murine mastocytoma. CTL-mediated, NK cell-mediated and lymphokine-activated killer (LAK) cell-mediated target-cell lyses were amplified by tamoxifen $(26,27)$. Correspondingly, using the P815 mastocytoma of DBA/2 mice, it was found that the anti-estrogenic drugs tamoxifen and toremifene increased the efficiency of immunotherapy by killer cells (28).

\section{EFFECTS OF OTHER SERMs ON IMMUNITY}

\section{Raloxifene}

In a study on healthy postmenopausal women, raloxifene treatment caused a significant decrease in serum interleukin-4 (IL-4) concentrations of patients compared to the placebo-control group (29).

Similar to tamoxifen, treatment with raloxifene exhibited suppression of estrogen-mediated effects on survival, maturation, and activation of autoreactive $B$ cells in NZB/W F1 mice (30). In addition, similarly to the effect of tamoxifen on dendritic cells, raloxifene reduced the immunostimulatory capacity of murine dendritic cells and inhibited their differentiation, though the drug-exposed dendritic cells displayed enhanced ability to internalize antigens (31). Furthermore, in experimental animals, raloxifene corrected thymic hypertrophy induced by ovariectomy; however, it decreased bone marrow $\mathrm{T}$ cell levels (32). In contrast, a report demonstrated that raloxifene did not modulate the thymic CD4+/CD8+ phenotypes, $\mathrm{T}$ cell responsiveness and inflammation in comparison with estrogen-mediated alterations in mice (33). 


\section{Toremifene}

Some researchers have found that in the blood, lymph nodes and tumors of breast cancer patients, the concentrations of toremifene and its active N-desmethyl metabolites reach a peak about 2 weeks after administration; the peak levels were higher than that of tamoxifen or N-desmethyltamoxifen. Furthermore, the concentrations of toremifene and $\mathrm{N}$-desmethyl metabolites of toremifene were higher in tumors and lymph nodes than in blood (34).

Similarly to tamoxifen, toremifene also augmented the immune oncolysis induced by various killer cells against human ovarian carcinoma cells and the human erythroleukemia cell line, K562 (35). It was noticed that in human peripheral blood T cells, both toremifene and tamoxifen inhibited mitogen-induced proliferation and up-regulated tumor necrosis factor (TNF) receptor family molecules (36). Conversely, tamoxifen was shown to be stimulatory for TNF $\alpha$ production in cultures of normal human peripheral mononuclear blood cells, but this feature was absent in the case of toremifene (37). Nevertheless, it was documented that toremifene exerts multiple and varied effects on the gene expression of human peripheral mononuclear cells (38). In a study conducted by Järvinen et al., using human cells in vitro, both tamoxifen and toremifene enhanced the T cell-dependent antibody production from B cells (39). In addition, they found that these drugs stimulated overall cytokine production in a B cell line (Ball). Interestingly, tamoxifen stimulated IL-1 $\beta$, IL-6 and IFN $\gamma$ production in a T cell line (Molt-4), whereas toremifene inhibited it. In their study, these two anti-estrogenic drugs showed no significant effects on cytokine production in myeloid cells (39).

\section{Ormeloxifene}

This non-steroidal SERM possesses contraceptive and anti-osteoclastogenic effects. Furthermore, the drug has been shown to have anti-cancer activities (40). Thomas et al. (41) demonstrated that ormeloxifene significantly increased the levels of serum immunoglobulins in mice. They concluded that ormeloxifene increased humoral immunity, but had an insignificant effect on cell mediated immunity.

\section{IMMUNE MODULATIONS OF AROMATASE INHIBITORS}

It was demonstrated in studies using malignant human breast tissue that aromatase activity in adipose tissue may have a close association with the cells of the immune system, particularly macrophages and the related cytokines $(42,43)$. Furthermore, the association between elevated aromatase levels and subclinical inflammation was more prominent in the breast tissue of most overweight and obese women (43).

\section{First-generation aromatase inhibitor (aminoglutethimide)}

Berry et al. (44) described an increase in NK cell activity in postmenopausal breast cancer patients on a low dose of aminoglutethimide, a first-generation aromatase inhibitor. 
An earlier report, using mouse tissue, demonstrated that aminoglutethimide enhanced delayed hypersensitivity and altered $\mathrm{T}$ lymphocyte distribution (45). It was also noticed that following daily administration of aminoglutethimide to female mice, significant dropping in white cell counts occurred after 3 weeks (46). However, another study documented greater proliferation of bovine $\mathrm{T}$ lymphocytes in cultures containing aminoglutethimide (47)

\section{Second-generation aromatase inhibitors}

Interestingly, tumor cells treated with formestane exhibited increased sensitivity to monocyte-mediated, antibody-dependent cellular cytotoxicity in metastatic breast cancer patients. Thus, a hormone-based treatment might collaborate with antigen-specific tumor immunity to create improved mechanisms for tumor control (48).

Formestane treated mice displayed an increased IL-2 and IFN $\gamma$ release and a decreased IL-10 release (49). On the other hand, fadrozole was associated with improvement of the cellular immune response and enhancement of IL-6 levels in male mice (50).

\section{Third-generation aromatase inhibitors}

Third-generation aromatase inhibitors include exemestane, anastrozole, letrozole and vorozole, the latter three being non-steroidal inhibitors. In a study on postmenopausal patients with breast cancer, Watanabe et al. (51) observed that exemestane administration could cause a decrease in lymphocyte counts. Alternatively, treatment with anastrozole was demonstrated to be associated with an increased expression of genes relating to inflammatory processes in ER+ breast tumors. Furthermore, there was enhanced induction of $\mathrm{T}$ cell anergy (unresponsiveness) in non-responders and induction of immune response in responders (52). In a comparative analysis of tamoxifen and anastrazole adjuvant treatments, total white blood cells of postmenopausal breast cancer patients were increased after one year of treatment with both anastrazole and tamoxifen; however, unlike tamoxifen, anastrazole did not change the lymphocyte count (53). Conversely, there was a reduction in regulatory $\mathrm{T}$ cells (T-reg cells) in letrozole treated elderly breast cancer patients and a greater T-reg reduction in responding patients, suggesting that the aromatase inhibitor letrozole may have an indirect anti-tumor action via its effects on immune mechanisms (54). Also, immunotherapy (with thymosin $\alpha 1$ ) reduced aromatase inhibitor (anastrozole, letrozole, or exemestane) related joint symptoms in postmenopausal breast cancer survivors, indicating involvement of immune phenomena with aromatase inhibitors (55).

Wang et al. (56) found that anastrozole suppressed the differentiation of naive $\mathrm{T}$ cells to T-reg cells, and it blocked the balance of IgG2a/IgG1 in peripheral blood of rats. In addition, anastrozole increased the levels of pro-inflammatory cytokines, IFN $\gamma$ and IL-12, and decreased IL-4 and IL-10 levels. 


\section{ANTI-ESTROGENIC DRUGS: CONNECTIONS WITH AUTOIMMUNE DISORDERS}

Due to the pleiotrophic nature of tamoxifen, its role in a variety of seemingly unrelated disorders, including multiple sclerosis, Parkinson's disease, Alzheimer's disease, systemic lupus erythematosus (SLE) and urological cancers, has been investigated in many studies (57).

Both anti-estrogens tamoxifen and toremifene were demonstrated to inhibit the maturation of human dendritic cells, a property that could be beneficial in the treatment and prevention of autoimmune diseases like rheumatoid arthritis $(58,59)$. Interestingly, Behjati and Frank (60) suggested a useful role of tamoxifen in the treatment of immune-mediated disorders, particularly of those arising from aberrant $\mathrm{T}$ helper 1 (Th1) cell activity, including allograft rejection and Th1-mediated autoimmune conditions like multiple sclerosis, owing to the capability of this drug to induce a shift from cellular ( $\mathrm{T}$ helper 1) to humoral (T helper 2) immunity. In this connection, it may be worth mentioning that by using mice, Bebo et al. (61) reported a suppressive role of SERMs like tamoxifen and raloxifene on myelin antigen specific $\mathrm{T}$ cell proliferation in experimental autoimmune encephalomyelitis.

Sereda and Werth observed an improvement in patients with dermatomyositis-associated skin eruptions while taking anti-estrogen medication (both tamoxifen and the aromatase inhibitor anastrozole) (62). Dermatomyositis is an autoimmune disease that occurs more often in women and causes inflammation of the skin and muscles. In a recent study, Babina et al. (63) found that tamoxifen treatment interfered with all aspects of the allergic immune response, leading to a reduction of allergen-specific immunoglobulin levels (IgE, IgG1 and IgG2a) and a skewing effect in the T cell compartment with the inhibition of IL-4 in mice sensitized with ovalbumin-alum by the intra-peritoneal route. Along with the systemic effects, there was a reduction in local pathologies like diminished epidermal thickness and decreased CD4+ and CD8+ cell infiltrates.

In recent years, a number of studies have tried to evaluate the beneficial immunological effects of anti-estrogenic drugs, notably tamoxifen, in SLE. Female subjects have a higher incidence of certain autoimmune diseases such as SLE and several studies have reported that estrogens accelerate the course of spontaneous SLE-like disease in NZB/W F1 and MRL-lpr/lpr mice. It was demonstrated that tamoxifen treatment could favorably influence T cells and modulate the immune function in MRL-lpr/lpr female mice (64). Similarly, in NZB/W F1 female mice, tamoxifen treatment showed fewer pathological features compared to controls by influencing the B cell count, expression of cytokine receptors and thereby overall immune function (65). Furthermore, in this mouse strain, autoantibody production directed against either nuclear extracts or DNA was significantly reduced by tamoxifen treatment (66). Interestingly, it was found in mice that tamoxifen prevented the activation of autoreactive B cells (67). These cells are deleted in normal conditions; however, their activation can cause an elevation of serum anti-DNA antibody titers.

Research concerning the immunomodulatory effects of LH-RH agonists and SERDs is limited and entirely non-existent for some specific anti-estrogenic drugs. Nevertheless, available current research concerning the effects of LH-RH agonists and SERDs on immune parameters has been tabulated in Table II (68-77). 
Table II. Effects of selective estrogen down-regulators and luteinizing hormone releasing hormone agonists on various immune parameters.

\begin{tabular}{|c|c|c|}
\hline Anti-estrogenic drug & Salient findings of the study & Reference no. \\
\hline Fulvestrant (SERD) & Fulvestrant depressed IgM in BALB/c mice. & 68 \\
\hline Fulvestrant & $\begin{array}{l}\text { Dendritic cell differentiation was inhibited by } \\
\text { fulvestrant. }\end{array}$ & 69 \\
\hline Fulvestrant & $\begin{array}{l}\text { In ovariectomized rats, fulvestrant inhibited the } \\
\text { anti-inflammatory activity exhibited by dexa- } \\
\text { methasone. }\end{array}$ & 70 \\
\hline Fulvestrant & $\begin{array}{l}\text { Significantly lower median values for the } \mathrm{T} \text { cell } \\
\text { activation markers CD154 and calcineurin in } \\
\text { the fulvestrant treated group. }\end{array}$ & 71 \\
\hline Leuprolide (LH-RH agonist) & $\begin{array}{l}\text { Leuprolide prevented stress-induced } \\
\text { immunosuppression. }\end{array}$ & 72 \\
\hline Leuprolide & $\begin{array}{l}\text { Leuprolide increased the number of lymphoid } \\
\text { and myeloid progenitor cells in the bone mar- } \\
\text { row and developing thymocytes in the thymus. }\end{array}$ & 73 \\
\hline Goserelin (LH-RH agonist) & $\begin{array}{l}\text { Goserelin treatment normalized cytokine pro- } \\
\text { duction in women with endometriosis. }\end{array}$ & 74 \\
\hline Buserelin (LH-RH agonist) & $\begin{array}{l}\mathrm{CD} 4+\mathrm{T} \text { cell and CD25+ T cell subpopulations } \\
\text { were significantly down-regulated when } \\
\text { buserelin was used for approximately } 2 \text { weeks. }\end{array}$ & 75 \\
\hline Buserelin & Buserelin treatment increased NK cell activity. & 76 \\
\hline Triptorelin (LH-RH agonist) & $\begin{array}{l}\text { In this drug treatment, an increase in NK cell } \\
\text { activity was observed among patients with } \\
\text { endometriosis who responded well to it. }\end{array}$ & 77 \\
\hline
\end{tabular}

\section{CONCLUSIONS}

The pathology of breast cancer has been shown to be associated with alterations of different components of body's immune machinery (78-81). It has been recently proposed that inflammation, in part due to tumor-associated macrophages and proinflammatory cytokines, may promote more aggressive ER-positive tumors and the suggested treatment includes targeting inflammation combined with anti-estrogenic drugs (82). Interestingly, various anti-estrogenic drugs have also been demonstrated to affect the immune system. The immunomodulatory effects described thus far include alterations in the function of lymphocytes, macrophages, monocytes and dendritic cells as well as effects on cytokines. Additionally, anti-estrogenic drugs have exhibited some immune modulations related to autoimmune disorders, possibly leading to other uses.

Apart from the hormonal property, many of these drugs may have other mechanisms of action through which they could modulate immune pathways and exert additional anti-tumor effects. Although adjuvant hormonal therapy substantially reduces the morbidity and mortality in both pre- and postmenopausal women with ER-positive early 
breast cancer, relapses occur frequently due to the development of drug resistance. Over the last several years we have observed considerable development in our understanding of the mechanisms of resistance to anti-estrogenic drugs. Resistance mechanisms may include phenomena such as activation of growth factor pathways like HER2/ neu signaling (83), enhanced concentrations of some hormone-like cytokines secreted from adipose tissue in obesity - particularly leptin (84), and mutations in the tumor suppressor gene p53 (85). Although some possible resistance mechanisms have been proposed, details of these mechanisms are unknown and there are probably some other factors. Alterations in host immunity might be an important factor in the development of resistance to anti-estrogenic agents in breast cancer patients. Therefore, gaining knowledge of the effects of anti-estrogenic drugs on immune function may bring us closer to elucidating some drug resistance pathways and possibly developing drugs with a higher long-term success rate. Nevertheless, the intricate pharmacology of anti-estrogenic agents is being slowly comprehended and this has resulted in new drug discoveries. In the near future, an increasing number of various biological molecules associated with estrogen will be used as targets for new treatment modalities.

\section{REFERENCES}

1. A. Ray and A. B. Mitra, Estrogen and breast cancer, ICMR Bull. 33 (2003) 13-24.

2. M. N. Okobia and C. H. Bunker, Epidemiological risk factors for breast cancer - a review, Niger. J. Clin. Pract. 8 (2005) 35-42.

3. T. Suzuki, Y. Miki, N. Ohuchi and H. Sasano, Intratumoral estrogen production in breast carcinoma: significance of aromatase, Breast Cancer 15 (2008) 270-277; DOI: 10.1007/s12282-008-0062-z.

4. I. Czajka-Oraniec and E. R. Simpson, Aromatase research and its clinical significance, Endokrynol. Pol. 61 (2010) 126-134.

5. W. C. Park and V. C. Jordan, Selective estrogen receptor modulators (SERMs) and their roles in breast cancer prevention, Trends Mol. Med. 8 (2002) 82-88; DOI: 10.1016/S1471-4914(02)02282-7.

6. G. T. Beatson, On the treatment of inoperable cases of carcinoma of the mamma: Suggestions for a new treatment with illustrative cases, Lancet 2 (1896) 104-107; DOI: 10.1016/S0140-6736 (01) 72384-7.

7. W. R. Miller, Oestrogens and breast cancer: biological considerations, Br. Med. Bull. 47 (1991) 470-483.

8. V. C. Jordan and W. J. Gradishar, Hormonal Therapy for Breast Cancer, in The Cancer Handbook (Ed. M. R. Alison), Vol. 2, Nature Publishing Group, London 2002, pp. 1449-1464.

9. P. Lonning, C. Pfister, A. Martoni and C. Zamagni, Pharmacokinetics of third-generation aromatase inhibitors, Semin. Oncol. 30 Suppl. 14 (2003) 23-32; DOI: 10.1016/S0093-7754(03)00305-1.

10. R. Stuart-Harris and A. Davis, Optimal adjuvant endocrine therapy for early breast cancer, Women's Health 6 (2010) 383-398; DOI: 10.2217/whe.10.25.

11. T. Delozier, Hormonal treatment in breast cancer, J. Gynecol. Obstet. Biol. Reprod. 39, Suppl. 8 (2010) F71-78; DOI: 10.1016/j.jgyn.2010.10.004.

12. D. P. McDonnell and S. E. Wardell, The molecular mechanisms underlying the pharmacological actions of ER modulators: implications for new drug discovery in breast cancer, Curr. Opin. Pharmacol. 10 (2010) 620-628; DOI: 10.1016/j.coph.2010.09.007.

13. F. Lumachi, G. Luisetto, S. M. Basso, U. Basso, A. Brunello and V. Camozzi, Endocrine therapy of breast cancer, Curr. Med. Chem. 18 (2011) 513-522; DOI: 10.2174/092986711794480177. 
14. A. Thomsen and J. M. Kolesar, Chemoprevention of breast cancer, Am. J. Health Syst. Pharm. 65 (2008) 2221-2228; DOI: 10.2146/ajhp070663.

15. C. Rivera-Guevara and J. Camacho, Tamoxifen and its new derivatives in cancer research, $R e$ cent Pat. Anticancer Drug Discov. 6 (2011) 237-245.

16. R. Weinshilboum, Pharmacogenomics of endocrine therapy in breast cancer, Adv. Exp. Med. Biol. 630 (2008) 220-231; DOI: 10.1007/978-0-387-78818-0_14.

17. H. Brauch, T. E. Mürdter, M. Eichelbaum and M. Schwab, Pharmacogenomics of tamoxifen therapy, Clin. Chem. 55 (2009) 1770-1782; DOI: 10.1373/clinchem.2008.121756.

18. R. Clarke, F. Leonessa, J. N. Welch and T. C. Skaar, Cellular and molecular pharmacology of antiestrogen action and resistance, Pharmacol. Rev. 53 (2001) 25-71.

19. A. Ring and M. Dowsett, Mechanisms of tamoxifen resistance, Endocr. Relat. Cancer 11 (2004) 643-658; DOI: $10.1677 /$ erc.1.00776.

20. C. M. Joffroy, M. B. Buck, M. B. Stope, S. L. Popp, K. Pfizenmaier and C. Knabbe, Antiestrogens induce transforming growth factor beta-mediated immunosuppression in breast cancer, Cancer Res. 70 (2010) 1314-1322; DOI: 10.1158/0008-5472.CAN-09-3292.

21. S. Rotstein, H. Blomgren, B. Petrini, J. Wasserman and L. V. von Stedingk, Influence of adjuvant tamoxifen on blood lymphocytes, Breast Cancer Res. Treat. 12 (1988) 75-79; DOI: 10.1007/BF01805743.

22. E. Robinson, D. Rubin, T. Mekori, R. Segal and S. Pollack, In vivo modulation of natural killer cell activity by tamoxifen in patients with bilateral primary breast cancer, Cancer Immunol. Immunother. 37 (1993) 209-212; DOI: 10.1007/BF01525437.

23. P. Mallmann and D. Krebs, Effect of tamoxifen on parameters of cell-mediated immunity in postmenopausal patients with breast carcinoma, Zbl. Gynakol. 113 (1991) 689-696.

24. J. Lukac, Z. Kusic, D. Kordic, M. Koncar and A. Bolanca, Natural killer cell activity, phagocytosis, and number of peripheral blood cells in breast cancer patients treated with tamoxifen, Breast Cancer Res. Treat. 29 (1994) 279-285; DOI: 10.1007/BF00666482.

25. M. E. Sabbioni, M. Castiglione, C. Hürny, H. P. Siegrist, M. Bacchi, J. Bernhard, B. Thürlimann, H. Bonnefoi, L. Perey, A. Goldhirsch and H. J. Senn, Interaction of tamoxifen with concurrent cytotoxic adjuvant treatment affects lymphocytes and lymphocyte subsets counts in breast cancer patients, Support. Care Cancer 7 (1999) 149-153; DOI: 10.1007/s005200050245.

26. E. Baral, E. Nagy, G. V. Krepart, R. J. Lotocki, H. W. Unruh and I. Berczi, Antiestrogens sensitize human ovarian and lung carcinomas for lysis by autologous killer cells, Anticancer Res. 20 (2000) 2027-2031.

27. E. Baral, E. Nagy, L. Kangas and I. Berczi, Anti-estrogens enhance the therapeutic effect of lymphokine-activated killer cells on the P815 murine mastocytoma, Int. J. Cancer 67 (1996) 580-585; DOI: 10.1002/(SICI)1097-0215(19960807).

28. E. Baral, E. Nagy, L. Kangas and I. Berczi, Combination immunotherapy of the P815 murine mastocytoma with killer cells, IL-2 and anti-estrogens, Anticancer Res. 17 (1997) 3653-3658.

29. S. Kumru, F. M. Yildiz, A. Godekmerdan, S. Kutlu, B. Yilmaz and B. Gurates, Effects of raloxifene and hormone replacement therapy on serum Th2 and Th3 type cytokine concentrations in healthy postmenopausal women: a randomised controlled trial, Arch. Gynecol. Obstet. 277 (2008) 489-493; DOI: 10.1007/s00404-007-0521-3.

30. Y. Zhang, S. Saha, G. Rosenfeld, J. Gonzalez, K. P. Pepeljugoski and E. Peeva, Raloxifene modulates estrogen-mediated B cell autoreactivity in NZB/W F1 mice, J. Rheumatol. 37 (2010) 1646-1657; DOI: 10.3899 /jrheum.090911.

31. G. Nalbandian, V. Paharkova-Vatchkova, A. Mao, S. Nale and S. Kovats, The selective estrogen receptor modulators, tamoxifen and raloxifene, impair dendritic cell differentiation and activation, J. Immunol. 175 (2005) 2666-2675. 
32. M. A. García-Pérez, R. Del Val, I. Noguera, C. Hermenegildo, B. Pineda, A. Martinez-Romero and A. Cano, Estrogen receptor agonists and immune system in ovariectomized mice, Int. J. Immunopathol. Pharmacol. 19 (2006) 807-819.

33. M. C. Erlandsson, E. Gomori, M. Taube and H. Carlsten, Effects of raloxifene, a selective estrogen receptor modulator, on thymus, $\mathrm{T}$ cell reactivity, and inflammation in mice, Cell. Immunol. 205 (2000) 103-109; DOI: 10.1006/cimm.2000.1719.

34. H. Masuoka, M. Mori, N. Nomura, M. Sakurai, K. Yoshida, N. Usuda, H. Shirai, I. Shimokawara and K. Asaishi, Assessment of post-administration body distribution of toremifene and tamoxifen, and their administration regimens, Jpn. J. Cancer. Res. 29 (2002) 881-887.

35. S. M. Haeryfar, E. Nagy, E. Baral, G. V. Krepart, R. J. Lotocki and I. Berczi, Antiestrogens affect both pathways of killer cell-mediated oncolysis, Anticancer Res. 20 (2000) 1849-1853.

36. J. Komi and O. Lassila, Antioestrogens enhance tumour necrosis factor receptor 2 (TNF-R2) expression and TNF-R2-mediated proliferation in activated T cells, Scand. J. Immunol. 48 (1998) 254-260; DOI: 10.1046/j.1365-3083.1998.00388.x.

37. J. Teodorczyk-Injeyan, M. Cembrzynska-Nowak, S. Lalani and J. A. Kellen, Modulation of biological responses of normal human mononuclear cells by antiestrogens, Anticancer Res. 13 (1993) 279-283.

38. J. A. Kellen, The effect of toremifene on the expression of some genes in human mononuclear cells, In Vivo 9 (1995) 215-217.

39. L. S. Järvinen, S. Pyrhönen, K. J. Kairemo and T. Paavonen, The effect of anti-oestrogens on cytokine production in vitro, Scand. J. Immunol. 44 (1996) 15-20; DOI: 10.1046/j.1365-3083.1996. d01-85.x.

40. P. Pal, J. K. Kanaujiya, S. Lochab, S. B. Tripathi, M. L. Bhatt, P. K. Singh, S. Sanyal and A. K. Trivedi, 2-D gel electrophoresis-based proteomic analysis reveals that ormeloxifen induces G0-G1 growth arrest and ERK-mediated apoptosis in chronic myeloid leukemia cells K562, Proteomics 11 (2011) 1517-1529; DOI: 10.1002/pmic.201000720.

41. L. Thomas, M. Asad, H. J. Hrishikeshavan and G. K. Chandrakala, Effect of centchroman on cellular and humoral immunity, Indian J. Physiol. Pharmacol. 51 (2007) 387-394.

42. A. Purohit, A. Singh, M. W. Ghilchik, O. Serlupi-Crescenzi and M. J. Reed, Inhibition of IL-6+ IL-6 soluble receptor-stimulated aromatase activity by the IL-6 antagonist, Sant 7, in breast tissue-derived fibroblasts, Br. J. Cancer 88 (2003) 630-635; DOI: 10.1038/sj.bjc.6600785.

43. P. G. Morris, C. A. Hudis, D. Giri, M. Morrow, D. J. Falcone, X. K. Zhou, B. Du, E. Brogi, C. B. Crawford, L. Kopelovich, K. Subbaramaiah and A. J. Dannenberg, Inflammation and increased aromatase expression occur in the breast tissue of obese women with breast cancer, Cancer Prev. Res. 4 (2011) 1021-1029; DOI: 10.1158/1940-6207.CAPR-11-0110.

44. J. Berry, B. J. Green and D. S. Matheson, Modulation of natural killer cell activity in stage I postmenopausal breast cancer patients on low-dose aminoglutethimide, Cancer Immunol. Immunother. 24 (1987) 72-75; DOI: 10.1007/BF00199836.

45. H. van Dijk and H. E. Jacobse-Geels, Evidence for the involvement of corticosterone in the ontogeny of the cellular immune apparatus of the mouse, Immunology 35 (1978) 637-642.

46. M. D. Coleman, L. F. Khalaf and P. J. Nicholls, Aminoglutethimide-induced leukopenia in a mouse model: effects of metabolic and structural determinants, Environ. Toxicol. Pharmacol. 15 (2003) 27-32; DOI: 10.1016/j.etap.2003.08.003.

47. M. J. Cannon, M. G. Petroff and J. L. Pate, Effects of prostaglandin F2alpha and progesterone on the ability of bovine luteal cells to stimulate T lymphocyte proliferation, Biol. Reprod. 69 (2003) 695-700; DOI: 10.1095/?biolreprod.103.017590.

48. D. P. Braun, K. A. Crist, F. Shaheen, E. D. Staren, S. Andrews and J. Parker, Aromatase inhibitors increase the sensitivity of human tumor cells to monocyte-mediated, antibody-dependent cellular cytotoxicity, Am. J. Surg. 190 (2005) 570-571; DOI: 10.1016/j.amjsurg.2005.06.013. 
49. C. P. Schneider, E. A. Nickel, T. S. Samy, M. G. Schwacha, W. G. Cioffi, K. I. Bland and I. H. Chaudry, The aromatase inhibitor, 4-hydroxyandrostenedione, restores immune responses following trauma-hemorrhage in males and decreases mortality from subsequent sepsis, Shock $\mathbf{1 4}$ (2000) 347-353.

50. J. Morales-Montor, C. Hallal-Calleros, M. C. Romano and R. T. Damian, Inhibition of p-450 aromatase prevents feminisation and induces protection during cysticercosis, Int. J. Parasitol. 32 (2002) 1379-1387; DOI: 10.1016/S0020-7519(02)00130-3.

51. T. Watanabe, M. Sano, M. Toi, T. Saeki, K. Kanda, S. Miura, H. Inaji, H. Sono, H. Saeki, R. Nishimura and Y. Fujita, Late phase II study of exemestane in postmenopausal patients with breast cancer resistant to anti-estrogenic agents, Gan. To. Kagaku. Ryoho. (Cancer \& Chemotherapy) 29 (2002) $1211-1221$.

52. M. Mello-Grand, V. Singh, C. Ghimenti, M. Scatolini, L. Regolo, E. Grosso, A. Zambelli, G. A. Da Prada, L. Villani, V. Fregoni, P. Baiardi, S. Marsoni, W. R. Miller, A. Costa and G. Chiorino, Gene expression profiling and prediction of response to hormonal neoadjuvant treatment with anastrozole in surgically resectable breast cancer, Breast Cancer Res. Treat. 121 (2010) 399-411; DOI: $10.1007 /$ s10549-010-0887-y.

53. B. Karagöz, O. Bilgi, A. Alacacioğlu, A. Ozgün, O. Sayan, A. A. Erikçi and E. G. Kandemir, Mean platelet volume increase after tamoxifen, but not after anastrazole in adjuvant therapy of breast cancer, Med. Oncol. 27 (2010) 199-202; DOI: 10.1007/s12032-009-9191-2.

54. D. Generali, G. Bates, A. Berruti, M. P. Brizzi, L. Campo, S. Bonardi, A. Bersiga, G. Allevi, M. Milani, S. Aguggini, L. Dogliotti, A. H. Banham, A. L. Harris, A. Bottini and S. B. Fox, Immunomodulation of FOXP3+ regulatory $\mathrm{T}$ cells by the aromatase inhibitor letrozole in breast cancer patients, Clin. Cancer Res. 15 (2009) 1046-1051; DOI: 10.1158/1078-0432.CCR-08-1507.

55. Q. Zhang, D. Tang and H. Zhao, Immunological therapies can relieve aromatase inhibitor-reated joint symptoms in breast cancer survivors, Am. J. Clin. Oncol. 33 (2010) 557-560; DOI: 10.1097/COC.0b013e3181cae782.

56. J. Wang, Q. Zhang, S. Jin, M. Feng, X. Kang, S. Zhao, S. Liu and W. Zhao, Immoderate inhibition of estrogen by anastrozole enhances the severity of experimental polyarthritis, Exp. Gerontol. 44 (2009) 398-405; DOI: 10.1016/j.exger.2009.03.003.

57. M. N. Singh, P. L. Martin-Hirsch and F. L. Martin, The multiple applications of tamoxifen: an example pointing to SERM modulation being the aspirin of the 21st century, Med. Sci. Monit. 14 (2008) 144-148.

58. J. Komi and O. Lassila, Nonsteroidal anti-estrogens inhibit the functional differentiation of human monocyte-derived dendritic cells, Blood 95 (2000) 2875-2882.

59. J. Komi, M. Möttönen, R. Luukkainen and O. Lassila, Non-steroidal anti-oestrogens inhibit the differentiation of synovial macrophages into dendritic cells, Rheumatology 40 (2001) 185-191; DOI: $10.1093 /$ rheumatology/40.2.185.

60. S. Behjati and M. H. Frank, The effects of tamoxifen on immunity, Curr. Med. Chem. 16 (2009) 3076-3080.

61. B. F. Bebo Jr, B. Dehghani, S. Foster, A. Kurniawan, F. J. Lopez and L. S. Sherman, Treatment with selective estrogen receptor modulators regulates myelin specific T-cells and suppresses experimental autoimmune encephalomyelitis, Glia 57 (2009) 777-790; DOI: 10.1002/glia.20805.

62. D. Sereda and V. P. Werth, Improvement in dermatomyositis rash associated with the use of antiestrogen medication, Arch. Dermatol. 142 (2006) 70-72.

63. M. Babina, F. Kirn, D. Hoser, D. Ernst, W. Rohde, T. Zuberbier and M. Worm, Tamoxifen counteracts the allergic immune response and improves allergen-induced dermatitis in mice, Clin. Exp. Allergy 40 (2010) 1256-1265; DOI: 10.1111/j.1365-2222.2010.03472.x. 
64. W. M. Wu, J. L. Suen, B. F. Lin and B. L. Chiang, Tamoxifen alleviates disease severity and decreases double negative T cells in autoimmune MRL-lpr/lpr mice, Immunology 100 (2000) 110-118; DOI: 10.1046/j.1365-2567.2000.00998.x.

65. W. M. Wu, B. F. Lin, Y. C. Su, J. L. Suen and B. L. Chiang, Tamoxifen decreases renal inflammation and alleviates disease severity in autoimmune NZB/W F1 mice, Scand. J. Immunol. 52 (2000) 393-400; DOI: 10.1046/j.1365-3083.2000.00789.x.

66. Z. M. Sthoeger, H. Zinger and E. Mozes, Beneficial effects of the anti-oestrogentamoxifen on systemic lupus erythematosus of (NZBxNZW)F1 female mice are associated with specific reduction of IgG3 autoantibodies, Ann. Rheum. Dis. 62 (2003) 341-346; DOI: 10.1136/ard.62.4.341.

67. E. Peeva, J. Venkatesh and B. Diamond, Tamoxifen blocks estrogen-induced B cell maturation but not survival, J. Immunol. 175 (2005) 1415-1423.

68. Y. Y. Dhaher, B. D. Greenstein, M. A. Khamashta and G. R. Hughes, Effects of oestradiol and the oestrogen antagonist Ici 182,780 on the delayed type hypersensitivity (DTH) index and on serum levels of IgM and IgG in ovariectomisedBalb/C and MRL/Mp-Lpr/Lpr mice, a model of systemic lupus erythematosus (SLE), Autoimmunity 33 (2001) 237-243.

69. V. Paharkova-Vatchkova, R. Maldonado and S. Kovats, Estrogen preferentially promotes the differentiation of $\mathrm{CD} 11 \mathrm{c}+\mathrm{CD} 11 \mathrm{~b}$ (intermediate) dendritic cells from bone marrow precursors, $\mathrm{J}$. Immunol. 172 (2004) 1426-1436.

70. S. Cuzzocrea, S. Bruscoli, C. Crisafulli, E. Mazzon, M. Agostini, C. Muià, E. Esposito, R. Di Virgilio, R. Meli, E. Vegeto, A. Maggi and C. Riccardi, Estrogen receptor antagonist fulvestrant (ICI 182,780) inhibits the anti-inflammatory effect of glucocorticoids, Mol. Pharmacol. 71 (2007) 132-144; DOI: $10.1124 / \mathrm{mol} .106 .029629$.

71. N. I. Abdou, V. Rider, C. Greenwell, X. Li and B. F. Kimler, Fulvestrant (Faslodex), an estrogen selective receptor downregulator, in therapy of women with systemic lupus erythematosus. Clinical, serologic, bone density, and $\mathrm{T}$ cell activation marker studies: a double-blind placebo-controlled trial, J. Rheumatol. 35 (2008) 797.

72. S. N. Umathe, P. V. Dixit, M. M. Wanjari and M. P. Ullewar, Leuprolide-a GnRH agonist-prevents restraint stress-induced immunosuppression via sex steroid-independent peripheral mechanism in mice, Int. Immunopharmacol. 8 (2008) 71-79; DOI: 10.1016/j.intimp.2007.10.011.

73. G. L. Goldberg, C. G. King, R. A. Nejat, D. Y. Suh, O. M. Smith, J. C. Bretz, R. M. Samstein, J. A. Dudakov, A. P. Chidgey, S. Chen-Kiang, R. L. Boyd and M. R. van den Brink, Luteinizing hormone-releasing hormone enhances $\mathrm{T}$ cell recovery following allogeneic bone marrow transplantation, J. Immunol. 182 (2009) 5846-5854; DOI: 10.4049/?jimmunol.0801458.

74. K. Szyllo, H. Tchorzewski, M. Banasik, E. Glowacka, P. Lewkowicz and A. Kamer-Bartosinska, The involvement of T lymphocytes in the pathogenesis of endometriotic tissues overgrowth in women with endometriosis, Mediators Inflamm. 12 (2003) 131-138; DOI: 10.1080/0962935031000134842.

75. H. N. Ho, H. F. Chen, S. U. Chen, K. H. Chao, Y. S. Yang, S. C. Huang, T. Y. Lee and T. J. Gill 3rd., Gonadotropin releasing hormone $(\mathrm{GnRH})$ agonist induces down-regulation of the CD3+ CD25+ lymphocyte subpopulation in peripheral blood, Am. J. Reprod. Immunol. 33 (1995) 243-252.

76. N. Umesaki, T. Tanaka, M. Miyama, K. Mizuno, N. Kawamura and S. Ogita, Increased natural killer cell activities in patients treated with gonadotropin releasing hormone agonist, Gynecol. Obstet. Invest. 48 (1999) 66-68; DOI: 10.1159/000010137.

77. G. G. Garzetti, A. Ciavattini, M. Provinciali, M. Muzzioli, G. Di Stefano and N. Fabris, Natural cytotoxicity and GnRH agonist administration in advanced endometriosis: positive modulation on natural killer activity, Obstet. Gynecol. 88 (1996) 234-240; DOI: 10.1016/0029-7844(96)00146-9.

78. M. E. Sabbioni, H. P. Siegrist, M. Bacchi, J. Bernhard, M. Castiglione, B. Thürlimann, H. Bonnefoi, L. Perey, R. Herrmann, A. Goldhirsch and C. Hürny, Association between immunity and prognostic factors in early stage breast cancer patients before adjuvant treatment, Breast Cancer Res. Treat. 59 (2000) 279-287; DOI: 10.1023/A:1006379925343. 
79. A. Ray, V. Gupta, R. Kant, R. Yadav, A. K. Bahadur, S. L. D. Naik, B. K. Sharma and N. S. Murthy, T-lymphocytes in breast cancer: association with prognostic factors and response to treatment, Ann. Natl. Acad. Med. Sci. 39 (2003) 105-115.

80. E. Pavoni, G. Monteriù, D. Santapaola, F. Petronzelli, A. M. Anastasi, A. Pelliccia, V. D'Alessio, R. De Santis and O. Minenkova, Tumor-infiltrating B lymphocytes as an efficient source of highly specific immunoglobulins recognizing tumor cells, BMC. Biotechnol. 7 (2007) 70; DOI: 10.1186/ 1472-6750-7-70.

81. V. N. Kristensen, C. J. Vaske, J. Ursini-Siegel, P. Van Loo, S. H. Nordgard, R. Sachidanandam, T. Sørlie, F. Wärnberg, V. D. Haakensen, A. Helland, B. Naume, C. M. Perou, D. Haussler, O. G. Troyanskaya and A. L. Børresen-Dale, Integrated molecular profiles of invasive breast tumors and ductal carcinoma in situ (DCIS) reveal differential vascular and interleukin signaling, Proc. Natl. Acad. Sci. U.S.A. 109 (2012) 2802-2807; DOI: 10.1073/pnas.1108781108.

82. S. C. Baumgarten and J. Frasor, Mini review: Inflammation: An instigator of more aggressive estrogen receptor (ER) positive breast cancers, Mol. Endocrinol. 26 (2012) 360-371; DOI: 10.1210/ me.2011-1302.

83. C. K. Osborne and R. Schiff, Mechanisms of endocrine resistance in breast cancer, Annu. Rev. Med. 62 (2011) 233-247; DOI: 10.1146/annurev-med-070909-182917.

84. M. E. Grossmann, A. Ray, K. J. Nkhata, D. A. Malakhov, O. P. Rogozina, S. Dogan and M. P. Cleary, Obesity and breast cancer: status of leptin and adiponectin in pathological processes, Cancer Metastasis Rev. 29 (2010) 641-653; DOI: 10.1007/s10555-010-9252-1.

85. H. S. Kim, C. K. Yom, H. J. Kim, J. W. Lee, J. H. Sohn, J. H. Kim, Y. L. Park and S. H. Ahn, Overexpression of p53 is correlated with poor outcome in premenopausal women with breast cancer treated with tamoxifen after chemotherapy, Breast Cancer Res. Treat. 121 (2010) 777-788; DOI: $10.1007 /$ s10549-009-0560-5.

\title{
$S A \check{Z} E T A K$
}

\section{Imunomodulatorni učinak antiestrogenih lijekova}

\author{
AMITABHA RAY i MONICA FICEK
}

Postoje značajni eksperimentalni, epidemiološki i klinički dokazi da na patologiju karcinoma dojke utječu endogeni hormoni. Zbog toga je snižavanje razine hormona najvažniji način terapije ove bolesti. Već više od tri dekade koristi se tamoksifen, kompetitivni parcijalni agonist-inhibitor receptora za estrogene. U suvremenoj terapiji koriste se još raloksifen, različiti inhibitori aromataze (posebno treća generacija inhibitora) i agonisti hormona za oslobađanje luteinizirajućeg hormona. U posljednje vrijeme sve više činjenica ukazuje na to da ti lijekovi imaju i imunomodulatorni učinak, tj. utječu na funkciju leukocita i oslobađanje različitih citokina. Štoviše, postoje dokazi da antiestrogeni lijekovi imaju povoljni učinak na neke autoimune bolesti. Međutim, njihov imunofarmakološki učinak nije do kraja objašnjen. Samo potpuno razumijevanje patofizioloških procesa može uroditi učinkovitom strategijom za prevenciju i terapiju te smanjenje mortaliteta od karcinoma dojke.

Ključne riječi: karcinom dojke, SERMs, tamoksifen, inhibitori aromataze, imunofarmakologija

Saint James School of Medicine, Albert Lake Drive, The Quarter A-1 2640, Anguilla, British West Indies 